\title{
THE TRANSBOUNDARY WATER MANAGEMENT - COMPARING POLICY TRANSLATIONS OF THE WATER FRAMEWORK DIRECTIVE IN THE INTERNATIONAL BASIN DISTRICTS OF THE ODER RIVER AND THE TORNE RIVER
}

\author{
Aleksandra Ibragimow @ ${ }^{1}$, Eerika Albrecht @ ${ }^{2}$, Moritz Albrecht @ ${ }^{2}$ \\ ${ }^{1}$ Collegium Polonicum Słubice, Adam Mickiewicz University, Poznań, Poland \\ ${ }^{2}$ Department of Geographical and Historical Studies, University of Eastern Finland, Joensuu, Finland
}

Manuscript received: June 7, 2018

Revised version: February 4, 2019

\begin{abstract}
Ibragimow A., Albrecht A., Albrecht M., 2019. The transboundary water management - comparing the policy translation of Water Framework Directive in two international basin districts of the Oder River and the Torne River. Quaestiones Geographicae 38(1), Bogucki Wydawnictwo Naukowe, Poznań, pp. 29-39. 1 fig, 2 tables.
\end{abstract}

ABSTRACT: The European Union's Water Framework Directive introduced a new approach to the system of water management in Europe by nominating the river basin district as the basic unit in water management. While its transboundary character aims to better manage natural resources, its design and implementation carries several challenges due to its weak integration of various bordering effects related to administrative boundaries that strongly affect the directives' implementation. Based on a comparative document based case study of two river basin districts - the International Oder River Basin District (IORBD) and the International Torne River Basin District (ITRBD) - the paper scrutinizes the effects on the implementation processes of the directive and aims to draw attention to identify the differences that derive from various socio-spatial settings during the first cycles of water management plans from 2009 to 2015. By thematically comparing biophysical characteristics, cross-border cooperation, cultural and administrative bordering processes the study displays a mismatch between the directives aims for transboundary governance and the actual governance processes which are hampered by a variety of conflicting bordering processes.

KEY WORDS: Water Framework Directive, water management, international river basin district, the Oder River, the Torne River

Corresponding author: Aleksandra Ibragimow, aleksandra.ibragimow@amu.edu.pl

\section{Introduction}

Since its enactment in 2000 the Water Framework Directive (WFD) has attracted wide scholarly attention (Boeuf, Fritsch 2016, Newig et al. 2016). Water governance is one of the most widely discussed topics in transboundary environmental governance literature with studies on river basin governance taking centre stage (e.g. Dore et al. 2012, Jager 2016). This is related to the fact that the EU member states were required to produce water management plans for the first implementation cycle of 2009-2015. This obligation has been regarded as a chance to improve the quality of transboundary water environment in Europe, but also has been the WFDs' greatest challenge. Studies have been analysing the aspects related to upstream/downstream management, conflicts and governance processes as well as on the workings of international policy 
frameworks for transboundary river basins (e.g. Jager 2016, Kochskämper et al. 2016). Yet, despite that many of the rivers in these cases present at the same time a lengthy national border, most studies lack to integrate the bordering processes that effect managing entities on either side of the bordering river (see Martinez 1994, van Houtum 2000, Newman 2006).

Transboundary water governance and river basin governance studies are predominantly framed within a multi-level/stakeholder framework emphasizing the scalar mis-fit of WFD implementation (e.g. Green et al. 2013, Newig et al. 2016). This leads to a partial description of transboundary water governance as it becomes strongly restricted to stakeholders and processes actively involved in policy processes while it marginalizes aspects deriving from the river as a de/re-bordering entity in itself (e.g. van Houtum 2005, van der Velde 2013, Ibragimow, Albrecht

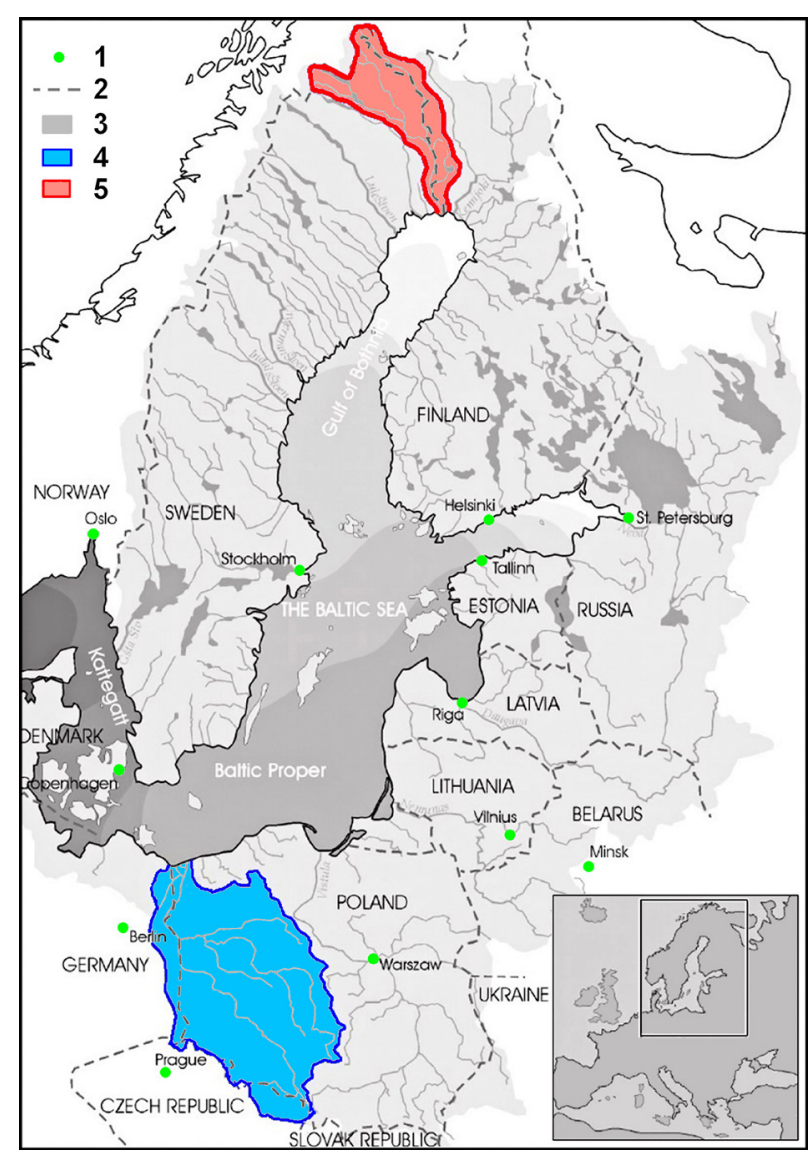

Fig. 1. Location of case study river basin management areas in the Baltic Sea catchment area.

1 - capitols, 2 - state borders, 3 - the Baltic Sea, 4 - the International Oder River Basin District, 5 - the International Torne River Basin District.
2015). Aside socio-spatial characteristics that shape environmental governance processes this further includes integration of biophysical aspects and the variegated understandings on the same that shape practices in relation to the former (Albrecht 2015, 2017).

In this paper the focus is on these existing gaps and to scrutinize a variety of bordering effects on transboundary water governance by the example of two international river basin districts: The International Oder River Basin District (IORBD) and the International Torne River Basin District (ITRBD) (Fig. 1). The aim of the study was to scrutinize transboundary water governance processes and to highlight the socio-spatial differences of bordering processes that guide diverse WFD implementation practices based on the following questions:

1. Which border related processes shaped WFD implementation during the first cycle of planning?

2. What kind of international river basin management is in place after the first implementation cycle of 2009 and 2015 ?

3. What has been the effect of bordering processes for harmonization of water management systems in Europe?

\section{Materials and Methods}

The IORBD and ITRBD are located in the northern, respectively the southern parts of the Baltic Sea Basin (Fig. 1, Table 1). Each cover the territory of three countries - the IORBD: Poland, Germany and Czech Republic, the ITRBD: Sweden, Finland and Norway.

The study is framed as a document-based qualitative thematic analysis on the implementation of the WFD between 2009 and 2015 and on policy documents from 5 EU countries: Finland, Sweden, Poland, Germany and Czech Republic for cross-border water management. Additional data was acquired through participatory observation and through discussions in an international conference on Implementing the Water Framework Directive and Flood Directive in the IORBD, in November 2015 in Wrocław, and the International conference on the United Nations Economic Commission for Europe (UNECE) Water Convention, in May 2017 in Haparanda at 
Table 1. Characteristics of the International Oder River Basin District (IORBD) and the International Torne River Basin District (ITRBD) according to Elfvendahl et al. 2006, ICOP 2009, 2014, Öhman et al. 2016.

\begin{tabular}{|c|c|c|}
\hline Characteristics & International Odra River Basin District & International Torne River Basin District \\
\hline Length of the river & $841 \mathrm{~km}$ & $520 \mathrm{~km}$ \\
\hline The area & $124115 \mathrm{~km}^{2}$ & $40000 \mathrm{~km}^{2}$ \\
\hline $\begin{array}{l}\text { The area / percentage of the } \\
\text { area in the different countries }\end{array}$ & $\begin{array}{c}107169 \mathrm{~km}^{2} / 86.4 \% \text { Poland } \\
9602 \mathrm{~km}^{2} / 7.7 \% \text { Germany } \\
7278 \mathrm{~km}^{2} / 5.9 \% \text { Czech Republic }\end{array}$ & $\begin{array}{c}25000 \mathrm{~km}^{2} / 64 \% \text { Sweden } \\
14000 \mathrm{~km}^{2} / 35 \% \text { Finland } \\
441 \mathrm{~km}^{2} / 1 \% \text { Norway }\end{array}$ \\
\hline $\begin{array}{l}\text { Annual runoff to the Baltic } \\
\text { sea }\end{array}$ & 18.5 billion $\mathrm{m}^{3}$ & $\begin{array}{l}\text { about } 17800 \text { million } \mathrm{m}^{3} \text { (strong annual } \\
\text { variation) }\end{array}$ \\
\hline $\begin{array}{l}\text { The human population in- } \\
\text { habiting the river basin area }\end{array}$ & $\begin{array}{l}\text { About } 16.7 \text { million in 2005: } \\
\text { - about } 14.2 \text { million in Poland; } \\
\text { - about } 1.6 \text { million in Czech Republic; } \\
\text { - about } 0.7 \text { million in Germany. }\end{array}$ & $\begin{array}{l}\text { About } 80000 \text { in 2012: } \\
\text { - } 35000 \text { in Finland; } \\
\text { - } 45000 \text { in Sweden. }\end{array}$ \\
\hline Ecoregions & $\begin{array}{l}\text { The Carpathians } \\
\text { The Eastern Plains } \\
\text { The Central Plains } \\
\text { The Central Uplands }\end{array}$ & $\begin{array}{l}\text { Central plain } \\
\text { Fenno-Scandian shield } \\
\text { Fenno-Scandian shield } \\
\text { Borealic uplands }\end{array}$ \\
\hline The main land use & $\begin{array}{c}\text { Agricultural land }(62 \%) \\
\text { Forests and semi-natural ecosystems } \\
(32 \%) \\
\text { Anthropogenic areas }(4 \%) \\
\text { Water areas }(2 \%)\end{array}$ & $\begin{array}{l}\text { Boreal forests }(58 \%) \\
\text { Tundra } \\
\text { Wetlands } \\
\text { Agricultural land }(0,5 \%) \\
\text { Mining and settlements }\end{array}$ \\
\hline Sources of contamination & $\begin{array}{l}\text { Historical and ongoing mining indus- } \\
\text { try, treated waste water from the main } \\
\text { towns, agriculture }\end{array}$ & $\begin{array}{l}\text { Treated waste water from the main towns, } \\
\text { settlements and industry, such as historical } \\
\text { and ongoing mining industry, forestry prac- } \\
\text { tices, peat mining, fish farming, agriculture }\end{array}$ \\
\hline Significant natural resources & Natura 2000 area & Naturally breeding salmon population \\
\hline
\end{tabular}

the secretariat of Finnish-Swedish Transboundary River Commission. Based on the analysed data the study compares 3 attributes of the two RBDs: the biophysical characteristics and their related definitions; the cross-border cooperation processes within the two river basins (before and after 2000) and the experiences deriving from the first cycle of water management plans (2009-2015) in relation to the implementation of WFD.

\section{Results}

\section{Cross-border cooperation before 2000}

Recognizing the Oder River as a main source of pollution for the Baltic Sea was one of the most important factors that initiated the development of cross-border cooperation in the field of water management and protection of its basin (Meyer 2002). The first Agreement on bilateral cooperation between Poland and Germany in the area of cross-border waters of the Oder and Lusitian Neisse was signed on 19 May 1992 and came into effect on 26 September 1996 (Umowa 1992). Its main aim was to guarantee the rational development and protection of the water and the improvement of its quality, as well as maintaining the ecosystems and, if needed, their restitution. Simultaneously, trilateral activities were undertaken between Poland, Germany and the Czech Republic. In 1996 these countries signed the Agreement on the International Commission for the Protection of the Oder River against Pollution (ICOP) (Umowa 1996). The activity of the ICOP was both conceptual and related to performance and aimed, among others, at preventing and permanent reduction of contamination of the Oder and the Baltic Sea with harmful substances, as well as at achieving water ecosystems, which would be as similar as possible to the natural ones. Moreover, a priority was also to enable obtaining drinking water from the infiltration bank intakes, the agricultural use of water and deposits, as well as preventing and reducing damage caused by flooding.

In the International Torne River Basin District the cross-border cooperation was launched to protect important natural resources in both countries, particularly in relation to the problems deriving from hydraulic engineering (e.g. hydro 
power) on local fish stock (Nilsson, Langaas 2006). First bilateral treaty between Finland and Sweden was signed in 1971 and was mainly regulating aspects related to hydraulic engineering and fishing activities in the Torne River (ibid.). Besides those initial agreements cooperation in cross-border water management issues has been increasing since the 1990's. First remarkable cooperation project was carried out to evaluate the status of the water quality in the Torne River basin in the end of 1990's. The project received funding from the Environmental Centre of Lapland (nowadays the Centre for Economic Development, Transport and Environment of Lapland), the County Administrative Board of Norrbotten and the Finnish-Swedish Transboundary River Commission (Puro-Tahvanainen et al. 2001). Throughout this period cooperation can be largely described as single problem oriented cooperation, rather than transnational policy driven common management targeted as is the aim under the present WFD.

\section{Cross-border cooperation after 2000}

The enactment of the WFD begins a new phase for the development of cross-border cooperation in both case study areas. EU policy with the WFD treats water management as cyclical process. In 2000 the process of WFD transposition to the EU

Table 2. Stakeholders on the area of the International Oder River Basin District (IORBD) and the International Torne River Basin District (ITRBD).

\begin{tabular}{|c|c|c|}
\hline River Basin District & Country & Institution \\
\hline \multirow[t]{19}{*}{$\begin{array}{l}\text { International Oder } \\
\text { River Basin District }\end{array}$} & \multirow[t]{8}{*}{ Germany } & $\begin{array}{l}\text { German Federal Ministry for the Environment, Nature Conservation and Nuclear } \\
\text { Safety in Bonn }\end{array}$ \\
\hline & & Ministry for Environment, Health and Consumer Protection Brandenburg \\
\hline & & $\begin{array}{l}\text { Ministry of Agriculture, the Environment and Consumer Protection Mecklen- } \\
\text { burg-Vorpommern }\end{array}$ \\
\hline & & Saxon State Ministry for the Environment and Agriculture \\
\hline & & State Office of Environment, Health and Consumer Protection Brandenburg \\
\hline & & National Office for the Environment, Nature Conservation and Geology \\
\hline & & State Bureau for Agriculture and Environment \\
\hline & & Saxon State Office for Environment, Agriculture and Geology \\
\hline & \multirow[t]{2}{*}{ Poland } & President of the National Water Management Authority \\
\hline & & Regional Water Management Board: in Gliwice, Wroclaw, Poznan, Szczecin \\
\hline & \multirow{9}{*}{$\begin{array}{l}\text { Czech } \\
\text { Republic }\end{array}$} & Ministry of the Environment \\
\hline & & Ministry of Agriculture \\
\hline & & T. G. Masaryk Water Research Institute \\
\hline & & Czech Environment Inspection \\
\hline & & Agency for Nature Conservation and Landscape Protection of the Czech Republic \\
\hline & & Czech Hydrometeorological Institute \\
\hline & & Labe River Basin Authority, state enterprise \\
\hline & & Ohře River Basin Authority, state enterprise \\
\hline & & Odra River Basin Authority state enterprise \\
\hline \multirow{13}{*}{$\begin{array}{l}\text { International Torne } \\
\text { River Basin District }\end{array}$} & \multirow[t]{7}{*}{ Finland } & Finnish-Swedish Transboundary River Commission \\
\hline & & Ministry of the Environment \\
\hline & & Centre for Economic Development, Transport and Environment of Lapland \\
\hline & & Water Management District of Tornionjoki \\
\hline & & Natural Resources Institute, Finland \\
\hline & & Finnish Environment Institute \\
\hline & & Municipalities \\
\hline & \multirow[t]{6}{*}{ Sweden } & Ministry of Environment and Energy \\
\hline & & County Administrative Board of Norrbotten \\
\hline & & Water authority of Bottenvik \\
\hline & & Swedish agency for marine and water management \\
\hline & & Geological survey of Sweden \\
\hline & & Municipalities \\
\hline
\end{tabular}


member states began, and numerous institutions from the countries whose territories comprise the IORBD and the ITRBD got involved (see Table 2). Following, since 2002 the ICOP and the ITRBD, framed within the WFD as a mobile EU policy, are institutionally required to coordinate activities related to tightening the cross-border cooperation directed to managing and identifying problems of the so called water bodies. This includes evaluation of the water bodies, their use, and assessment of their current status, the identification of significant current and future anthropogenic pressures and economic analyses of water uses. Besides, incorporation of economic instruments and the requirement for public participation needs to be included (Page, Kaika 2003). In addition to their responsibilities framed by the WFD documents, the implementation of the same is dependent on a variety of existing policies and practices that differ between the countries (Keskitalo, Petterson 2012). The WFD implementation phase of 2009-2015 therefore provides us with an experimental setting to analyse how the policy was translated differently and what where the reasons for these varying approaches (e.g. Albrecht et al. 2017).

\section{The International Oder River Basin District}

Following the WFD establishment, implementation in Poland, Germany and the Czech Republic was guided by varying translations of the policy and its requirements. One reason for varying implementation are the constitutional statuses within the countries as cross-border water management requires legal involvement of both regional and national institutions with varying responsibilities. The cooperation in the field of water management between relevant state offices and institutions is challenging and even more so if activities are jointly managed among different countries (Green et al. 2013). Additionally, the scope of duties and legal powers by relevant offices and institutions on the national level differ significantly which hinders to find a common ground for communication and exchange of experience (Knippschild 2011, Sarmiento-Mirwaldt, Roman-Kamphaus 2013, Ibragimow, Albrecht 2015).

One of the first and most important tasks in the IORBD was designating the cross-border water bodies, and, if necessary, defining them as artificial or heavily modified. A common agreement was required to assure the uniform treatment and classification of cross-border water bodies. This question is extremely important as it is the basis for defining the appropriate range of ecological monitoring, comprising the assessment of ecological conditions or ecological potential. In 2010, when the first RBMP in the IORBD was being developed, a common agreement was not achieved, and cross-border water bodies were characterized nationally. Still by 2014 while updating the first RBMP a common agreement on international characteristics was not reached for all cross-border water bodies (ICOP 2014).

Another crucial question concerns the determination of the chemical condition of cross-border water bodies, which is assessed uniformly on the basis of endurance, bioaccumulation and toxicity of substances dangerous for the environment. The term priority substances is used to refer to them and they include for example trace metals such as cadmium, lead, nickel and mercury and their compounds. For these substances environmental quality norms have been defined in accordance with the WFD. In the area where the Oder marks the national border, the monitoring of water is carried out in accordance with bilateral international agreement on the cooperation in the field of water management on border waters concluded in 1992 between the governments of Poland and Germany (Umowa 1992). Its scope and frequency of analyses are defined based on the international agreements; whose modification is dependent on the arrangements of the Working Group W2 "Water Protection" of the Polish-German Commission for Border Waters. The monitoring comprises joint Polish-German collection of samples in order to compare the obtained results between the laboratories of the Polish Regional Inspectorates for Environmental Protection and adequate Ministries of Brandenburg, Sachsen and Mecklenburg Western Pomerania (IOŚ 2006). The results of the analyses are presented in the form of reports on the quality of Polish-German border waters (e.g. IOŚ 2013, Polsko-Niemiecka Komisja Wód Granicznych 2014). These reports present, among others, the mean annual values of chemical elements concentrations in border waters. However, this practice changes in areas where the river is not 
a border river and the assessment of the chemical condition of cross-border water bodies is then performed based on national methodologies. In the case of the Polish-German cross-border water bodies this question is of crucial importance as the systems of classification used in both countries differ. Further, the methods of collecting and processing data, and sometimes methodological approaches, differ. In Germany, the LAWA classification system of the contamination degree of particular elements in the water ecosystem -water, suspension and deposits - is used (LAWA 1998). In Poland, while before August 2008 there was no legal basis for the assessment of surface water the 2008 regulation of the Minister of the Environment on the classification of cross-border water bodies (Rozporządzenie 2008), and following regulations (Rozporządzenie 2011) remain below the LAWA classification standards. At present, the classification of the condition of border uniform water bodies and the environmental quality norms for priority substances are based on the regulation of the Minister of the Environment of 2014 (Rozporządzenie 2014). No standardized assessment of water quality in the IORBD is planned in the future due to the fact that each member country participates in several basin areas. Hence, the possibilities of comparison within and between international river basin areas are significantly limited.

The analyses and studies conducted in the IORBD in the recent years, with special consideration of cross-border water bodies, allowed for the identification of crucial extra-regional problems related to water management (ICOP 2009). The first water management plan (ICOP 2009), as well as its update (ICOP 2014), stressed that high contamination of water with priority substances is one of the main extra-regional problems of water management. What is more, it was stressed that in the second cycle of water management planning (2016-2021), this problem disables the assessment of good condition of surface water, and currently make it impossible to reach the water management aims. In this case, Art. 4 of the WFD (EC 2000) is applied, providing the possibility to prolong implementation of planned environmental aims if justification is provided. For the border length of the Oder River, such justification is the lack of technical possibilities necessary for the improvement of water condition quality, disproportionally high expenditures and natural conditions which restrict the improvement of water conditions.

The Water Management Plan for the IORBD involves basic and complementary actions, which should improve surface water quality in its area (ICOP 2014). They are defined on the basis of national studies and compared among the countries. For example, in Poland activities comprise the construction of new sewage treatment plants, reconstruction of existing plants, and remediating contamination from old landfills or post-industrial sites. In Germany, the contamination with harmful substances shall be gradually reduced by recultivating old landfills and by remediating other identified sources of pollution. In the Czech part of the IORBD, projects of construction and reconstruction of sewage systems, building, increasing effectiveness and modernizing the sewage treatment plants are planned. The above mentioned activities are listed in specific categories and presented in tables while the lack of uniform attitude, and the differing aspects taken into consideration during the classification processes of specific undertakings in each of the above mentioned countries are characteristic for the restraining properties towards a joint policy translation. Thus, possible resulting in a mismatch between certain expectations and actual implementation within IORBD authorities and sites.

\section{The International Torne River Basin District (ITRBD)}

Contrary to the IORBD countries, institutions in Finland and Sweden seem to have few difficulties to find common ground for communication and exchange of experience on water governance as the administrative structures are close to uniform and water quality targets are reached for $81 \%$ of water bodies. On the $10^{\text {th }}$ of October 2010 entered into the force the Agreement between Finland and Sweden Concerning Transboundary Rivers, which established the Finnish-Swedish Transboundary River Commission (FSTRC) with a legal capacity in both countries. The FSTRC aims at advancing the co-operation between the stakeholders and different sectors in the ITRBD and defines exchange of information between the regional authorities as one of its main tasks (FSTRC 2014). It distributes information on 
ongoing water management and fisheries projects in the ITRBD area, comments on environmental permit issues varying from waste water treatment plant, wind power plant, import terminal to peat extraction and dredging (FSTRC 2011-2015). Further, the FSTRC is responsible to organize events and since 2011, for the Torne valley water parliament, a forum for co-operation on the water environment. Founded in 2007, the water parliament is a discussion forum between Finland and Sweden. Sessions are bi-annual and are open to the public (Öhman et al 2016).

Fisheries issues are frequently on the commission agenda, as salmon fishing is an important part of Torne river basin districts livelihood and culture. Salmon stocks have been low at the end of 1990's but the action taken throughout the 2000's to reduce water pollution at the inner coastal areas of the Baltic sea have proven successful to restore the population. During the summers 2014 and 2016 the number of about 100000 salmon were returning to the Torne for breeding (Palm et al 2018). Despite the increase in the number of salmons that are returning to the Torne River for breeding, there are still threats to the salmon that may be caused by pollution or diseases. Thus, conservation of the salmon and trout is an area where the co-operation needs to be strengthened and the Swedish water authority, Vattenmyndigheten Bottenvik, suggested the development of a salmon conservation strategy for the Torne (FSTRC 2015). Nowadays about $50 \%$ of the salmon catch in the Baltic Sea Drainage Basin is from the Torne (Havs och vattenmyndigheter 2016). The FSTRC worked to harmonize fishing practices at the Torne River and the Bothian Bay, as Sweden has been about one week ahead of Finland for the start of Salmon fishing season on the Baltic Sea coastline (FSTRC 2015). This has caused conflicts among local fishermen in the Torne River basin district and has been contested due to the principle of equal treatment and non-discrimination, both guiding principles of the European Union. In Sweden salmon belongs to the midsummer table, a deeply embedded cultural tradition that has hindered previous discussions to change the Swedish fishing season to commence at a later time and match the Finnish starting date. Contrary, the previous Finnish rule set the 17th of June as the earliest starting time for salmon fishing (Ministry of Agriculture and
Forestry 2011) and was based on economic reasoning. Finally, in 2017 salmon fishing season start was harmonized and both parties agreed to the earliest starting time, allowed in the fishing rule by the FSTRC. The earlier starting time for the fishing season was reasoned as a sustainable solution on economic basis, as prices for salmon are higher in the beginning of the fishing season (Ministry of Agriculture and Forestry 2017a, b).

Main co-operation between Finland and Sweden has been actualized through Interreg Nord projects: The Torne River International Watershed, TRIWA I, II and III from 2005 to 2013. The cooperation between Finnish and Swedish authorities deepened in 2005-2006 when the TRIWA I Interreg IIIA project was carried out. The project was comparing Finnish and Swedish typologies and developing a harmonized TRIWA typology of ecoregions (mountain, inland and coastal regions), size classes of lakes (3 classes) and river catchments ( 3 classes) and classification of the humic content of the water (clear/brown) (Alanne et al, 2005; Elfvendahl et al. 2006). The work to deepen the cross-border cooperation of the Torne River watershed continued with TRIWA II Interreg IIIA project in 2006-2008 that aimed at harmonized management of the Torne River watershed. The project compared Finnish and Swedish water legislation and collected best practices for water management from both countries. Additionally, a continuation to the previous cooperation projects TRIWA III Interreg IVA North project (programme period 2007-2013) assessed the impact of forestry practices and the need for restoration of the rivers in the Torne River basin district. Forestry affects surface waters in the North of Fennoscandia, especially through ditching of peatlands. Same methods were applied in both countries such as analysing maps, field visits and cost-effectiveness analysis for restoration. The weakness of this approach was that other influence from human activity was not taken into account. Results of the TRIWA III showed that water systems were close to natural state in Sweden whereby in Finland influence of the forestry practices were clearly visible (Alanne et al. 2014). Despite this harmonizing efforts and existing practices classifications and nationally based monitoring activities remain different based on legal requirements to follow national systems. 
Study of Jager (2016) connects the economic integration of the regions towards their interest in deepening the cross-border water basin management. As the Torne River basin district is a peripheral region, thus not a main region for economic development and distant to the national economic centres and central administration, despite the long tradition in bilateral ties and strong interaction in variety of areas between Finland and Sweden, the WFD implementation has not yet actualized as a common river basin management plan - only national water management plans and programme of measures (2009) are in place. (Tornionjoen vesienhoitoalue 2009a, b; Vattenmydighet Bottenviken, Länsstyrelsen Norrbotten, 2010a).

In Sweden the Programme of Measures (PoM) identifies the problem areas in the river basin but contains only a very short chapter regarding common transnational measures, most of which are administrative (COM 2012). In the Finnish PoM, the main measures focus on improving the water supply and sewage in the sparsely populated areas, ground water protection, reducing the detriment of floods, reducing the impacts of hydraulic engineering and water system restoration (Tornionjoen vesienhoitoalue, 2009b).

The shortcoming is attributed to organizational differences in the: methodologies, planning timetables and national guidelines (Öhman et al. 2016). Monitoring activities are performed by the regional authorities and water management authorities of each country. Sweden applies the 'one out - all out' principle, which means that the overall status is defined according to the weakest quality criteria, whereby Finland uses a combined methodology, where only hydro-morphological factors may reduce the water status (Öhman et al. 2016). In Sweden, the monitoring data and maps are gathered in the internet portal VISS (VattenInformations System Sverige), which functions as an information basis for the co-operation (Vattenmydigheten Bottenviken, Länsstyrelsen Norrbotten, 2010b). Most of the water bodies in ITRBD are under relatively light surveillance since no activities take place that could threat the excellent or good condition of waters. In both regions in the ITRBD, maintaining the same level of nutrition and organic matter load is set as an objective to the water systems that are in good or high condition. However, the water systems that are degraded through silt from forestry practices require restoration. Restoration is also necessary in river beds that were altered for the log floating, a commonly used practice in the past.

Priorities of water management activities and funding focus on differing problem areas as for instance in the IORBD. A draft of an international river basin management plan for the second implementation phase from 2016-2021 has been discussed, although has not materialized to date (FSTRC 2016). This indicates that many obstacles to a harmonized cross-border water management remain.

\section{Discussion and conclusions}

Although a scalar misfit is often reported in scholarly publications on the WFD implementation (Evers 2016, Hüesker, Moss 2015), other obstacles for reaching the WFD objective of good ecological status and harmonized practices are an important factor. Hence, to understand regional translation and implementation the biophysical characters of the river basin, its socio-economic patters and historical dependencies must be integrated and connected with processes related to transnational policy workings. There is a need for more detailed comparisons that combine the biophysical characters, administrative structures and socio-cultural peculiarities to better understand the governance processes of the river basin management. The analyses, activities and prognoses undertaken during the implementation phase from 2009 and 2015 show mixed results in relation to the aim of improved water quality. In the case of the IORBD, with a special consideration of Polish-German border waters, achieving the environmental aim stipulated in the WFD - that is good condition of water - is highly unlikely. This is related to, among others, the extra-regional problem of water management, which is the contamination of water with priority substances, as well as trace metals. In the case of ITRBD the good condition of water has been reached for most part of the basin, as the river basin is in natural condition in most part of the Swedish side and the scattered loading from forest industry, agriculture, semi-rural and rural settlements and industry is comparable modest. 
The study shows that lack of cooperation or rather mismatch between the aims and structures of the regions in the international river basin districts are slowing down or preventing the implementations of measures within the scope of WFD. This can be partly attributed to legislative and institutional constraints which could be linked to what Agnew calls the territorial trap (Agnew 1994) yet are further bound to priorities in the national centres and to powers of reach (Allen 2011) in how those institutions are able to dominate the political priorities of the respective regions. While, this study indicates that sufficient exchange of information takes place in the river basin districts, the necessary actions for the improved water quality struggle to overcome these institutionalized, national and regional boundaries.

Border specific socio-cultural barriers that frame institutional collaboration (van Houtumn 2000), restrict the emergence of these necessary actions in the IRBDs. Based on the larger variations of these aspects between Poland in Germany than between Finland and Sweden (see e.g. Nilsson, Langaas 2006) the RBDs are framed by a different level of institutional uniformity. Although river basin management institutions exist, the tradition of managing environmental and water issues through regional administration is still in place in all countries of our comparison. This renders EU's WFD open to multiple complex regional translation processes based on rationalities in a variety of institutions and consequently result in a variety of policy implementation pathways (Mukhtarov 2014, Albrecht 2017, Albrecht et al. 2017). In Germany the Federal states, in Finland the centres for economic development, transport and environment and in Sweden the County Administrative Boards, in Poland President of the National Water Management Authority and in the Czech Republic Ministry of the Environment are responsible for the river basin districts. Additionally, water management priorities differ among states and even regions, which can result in a lack of resources to jointly implement the monitoring and data gathering requirements, while for instance infrastructure developments with an economic gain (e.g. water route development, hydro power) might be favoured.

Common actions aiming at solving the contamination of water bodies and the necessity to identify main spots and areal sources of pollution, have been undertaken in the Polish-German border area, and the enactment of the WFD has clearly intensified previously undertaken actions. However, when looking at the concerted transboundary management efforts the first years of introducing the Directive in the IORBD and the ITRBD as well as the experiences of the first cycle of water management planning (2009-2015) show that there remain critical aspects in both of the river basin districts. The implementation of particular activities in the field of water management is the duty of offices and institutions of each member country, in whose cases finding a common international platform of communication and exchange of experiences is largely hampered. This is in the IORBD district related to different constitutional statuses of Poland and Germany that have led to different distribution of competences and tasks between their local governmental levels. In the case of the IORBD, this is of special importance. In the case of ITRBD it is less difficult to find common ground as the administrative structures of Finland and Sweden are rather similar, however the Finnish-Swedish border river commission is mainly a platform to exchange information and harmonize practices. A Swedish-Finnish programme of measures was not in place during the first implementation phase from 2009 to 2015, which indicates that there are challenges in harmonizing the practices of member countries. Both international river basin districts contain peripheral characteristics. The international water management based on the transnational characteristic of the IRBDs is linking the distant regions closer to the centres of national and EU decision-making yet, the river and the surrounding communities and the cultures they represent remain part of the daily interactions of problem solving and learning (Kooiman, Bavinck 2005). The harmonization efforts of Salmon fishing practices on the Baltic Sea coast line, which is still part of the ITRBD, demonstrate that cultural practices, such as the importance of getting the Torne River salmon to the midsummer table, in many case more important than the ecological limits.

Another question relates to differences in assumed characteristics, classifications and criteria, conditioned by the binding state methodologies. This is, among others, related to varied 
characteristics and preferences in management of cross-border water bodies and different state methodologies of assessing the chemical condition of water. The study has highlighted a pressing need to analyse and adjust transnational classification processes in water governance. Thus, it should be acknowledged in water governance that policy instruments of EUs' WFD, such as classification processes underlie translation processes that are framed not solely on national and regional socio-spatial settings (Clarke et al. 2015, Albrecht et al. 2018) but additionally by the bordering processes of these transboundary environments rather than being a mere matter deriving from biophysical facts or institutional frameworks alone as often portrayed in the debates of national classification systems.

\section{Acknowledgments}

The authors are extremely thankful to the Adam Mickiewicz's University for financial support of the research. The authors wish to thank two anonymous reviewers and Zbigniew Zwoliński, for their valuable suggestions and corrections.

\section{Author's contribution}

The authors divide the contribution percentage as follows: Aleksandra Ibragimow - 45\%, Eerika Albrecht 35\%, Moritz Albrecht - 20\%.

\section{References}

Agnew J., 1994. The territorial trap: The geographical assumptions of international relations theory. Review of international Political Economy 1(1): 50-83.

Alanne M., Brannstrom G., Elfvendahl S., Liljaaniem P., Raina P., Salonen N., 2005. TRIWA project - The River Torne International Watershed. Development of a common typology for surface waters of River Torne international river basin district. Lapland Regional Environmental Centre, County Administrative Board of Norrbotten.

Alanne M., Bergman E., Johannson M., Kangas M., Rydstrom G., 2014. Triwa III - Forestry impact and water management in the Torne international river basin. Lapin elinkeino-, liikenne-, ja ympäristökeskus, raportteja 69, Erweko Oy, Rovaniemi.

Albrecht M., 2015. Enlightenment in Norway's Oil Shadow? Governance assemblages of a wood-based district heating network in Norway's' Inland Region. Journal of Environmental Policy and Planning 17(3): 381-401.

Albrecht M., 2017. The role of translation loops in policy mutation processes: State designated Bioenergy Regions in
Germany. Environment and Planning C: Politics and Space 35(5): 898-915.

Albrecht M., Kortelainen J., Sawatzaky M., Lukkarinen J., Rytteri T., 2017. Translating bioenergy policy in Europe: Mutation, aims and boosterism in EU energy governance. Geoforum 87: 73-84.

Allen J., 2011. Topological twists: power's shaping geographies. Dialogues in Human Geography 1(3): 283-298.

Boeuf B., Fritsch O., 2016. Studying the implementation of the Water Framework Directive in Europe: a meta-analysis of 89 journal articles. Ecology and Society 21(2): 19. DOI: 10.5751/ES-08411-210219.

Clarke J., Bainton D, Lendvai N., Stubbs P., 2015. Making Policy Move: Towards a Politics of Translation and Assemblage. Policy Press, Bristol.

COM, 2012. Commission staff working document. European Commission, Brussels.

Dore J., Lebel L., Molle F., 2012. A framework for analysis transboundary water governance complexes, illustrated in the Mekong Region. Journal of Hydrology 466-467: 23-36. DOI: 10.1016/j. jhydrol.2012.07.023.

EC 2000, Directive 2000/60/EC of the European Parliament and of the Council of 23 October 2000 establishing a framework for Community action in the field of water policy.

Elfvendahl S., Liljaniemi P., Salonen N., 2006. The River Thorne International Watershed. Common Finnish and Swedish typology, reference conditions and a suggested harmonized monitoring programme, Country Administrative Board of Norrbotten, Rovaniemi.

Evers M., 2016. Integrative river basin management: challenges and methodologies within the German planning system. Environmental Earth Sciences 75:1085, DOI: 10.1007/s12665-016-5871-3

FSTRC, 2011. Annual report. Swedisch Match, Stockholm. FSTRC, 2012. Annual report. Swedisch Match, Stockholm. FSTRC, 2013. Annual report. Swedisch Match, Stockholm. FSTRC, 2014. Annual report. Swedisch Match, Stockholm. FSTRC, 2015. Annual report. Swedisch Match, Stockholm. FSTRC, 2016. Annual report. Swedisch Match, Stockholm.

Green O., Garmestani A., van Rijwick H., Keessen A., 2013. EU Water governance: Striking the right Balance between Regulatory Flexibility and Enforcement? Ecology and Society 18(2): 10-20.

Havs och vattenmyndigheter, 2016. Årsredovisning 2016. Göteborg.

Hüesker F., Moss T., 2015. The Politics of Multi-scalar Action in: River Basin Management: Implementing the EU Water Framework Directive (WFD). Land Use Policy 42: 38-47.

Ibragimow A., Albrecht M., 2015. New/Old challenges for German-Polish cross-border cooperation since Polish accession to the Schengen Area: The twin cities of Słubice and Frankfurt (Oder). Europa Regional 23: 33-45.

ICOP, 2009. Plan Gospodarowania Wodami dla Międzynarodowego Obszaru Dorzecza Odry. Wrocław.

ICOP, 2014. Aktualizacja Planu Gospodarowania Wodami dla Międzynarodowego Obszaru Dorzecza Odry, Projekt. Wrocław.

IOŚ, 2006. Państwowy Program Monitoringu Środowiska na Obszarze Województwa Lubuskiego na rok 2006. Zielona Góra 2006.

IOŚ, 2013. Ocena jakości wód rzek granicznych w ramach wspótpracy międzynarodowej w latach 2010-2012. Zielona Góra.

Jager N. W., 2016. Transboundary Cooperation in European Water Governance - A set-theoretic analysis of Interna- 
tional River Basins. Environmental policy and governance 26: 278-291.

Keskitalo C., Petterson M., 2012, Implementing multi-level governance? The legal basis and implementation of the EU Water Framework Directive for forestry in Sweden. Environmental Policy and Governance 22: 90-103.

Knippschild R., 2011. Cross-Border Spatial Planning: Understanding, Designing and Managing Cooperation Processes in the German-Polish-Czech Borderland. European Planning Studies 19(4): 629-645.

Kochskämper E., Challies E., Newig J., Jager N.W., 2016. Participation for effective environmental governance? Evidence from Water Framework Directive implementation in Germany, Spain and the United Kingdom. Journal of Environmental Management 181(1): 737-748.

Kooiman J., Bavinck M., 2005. The governance perspective. In: J. Kooiman, M. Bavinck, S. Jentoft, R. Pullin (eds), Fish for life. Interactive governance for Fisheries. Amsterdam University Press, Amsterdam: 11-24.

LAWA [Länderarbeitsgemeinschaft Wasser], 1998. Zielvorgaben zum Schutz oberirdischer Binnengewässer, Band II: Ableitung und Erprobung von Zielvorgaben zum Schutz oberirdischer Binnengewässer für die Schwermetalle Blei, Cadmium, Chrom, Kupfer, Nickel, Quecksilber und Zink. Berlin.

Martinez O.J., 1994. Border people: life and society in the U.S.-Mexico borderlands. University of Arizona Press. Tucson.

Meyer A.K. (eds.), 2002. Zanieczyszczenie rzeki odry - Wyniki Międzynarodowego Projektu Odra (IOP). Universität Hamburg, Hamburg.

Ministry of Agriculture and Forestry, 2011. The Fishing Rule, Memorandum on the $21^{\text {st }}$ of April 2011.

Ministry of Agriculture and Forestry, 2017a, Lohen kalastusta aikaistetaan Pohjanlahdella - Säätely perustuu tutkittuun tietoon.

Ministry of Agriculture and Forestry, 2017b, Valtioneuvoston asetukset lohen kalastuksen rajoituksista Pohjanlahdella ja Simojoessa, sekä Tornionjoen edustan merialueella. Memorandum on the $31^{\text {st }}$ of January 2017.

Mukhtarov F., 2014. Rethinking the travel of ideas: Policy translation in the water sector. Policy $\mathcal{E}$ Politics 42(1): 71-88.

Newig J., Schulz D., Jager N.W., 2016. Disentangling puzzles of spatial scales and participation in environmental governance - The case of governance re-scaling through the European Water Framework Governance. Environmental management 58(6): 998-1014. DOI: 10.1007/s00267-0160753-8.

Newman D., 2006. The lines that continue to separate us: borders in our 'borderless' world. Progress in human geography 30(2): 143-161.

Nilsson S., Langaas S., 2006. International river basin management under the EU framework directive: An assessment of cooperation and water quality in the Baltic sea drainage basin. Ambio 35(6): 304-311.

Öhman C., Elfvendahl S., Lundstedt L., Luokkanen E., Puro-Tahvanainen A., Raina P., Sallinsalmi V., 2016. Finnish-Swedish Transboundary River Commission: Borderless water management 2016-2021. Lääninhallituksen julkaisusarja 2. Rovaniemen painatuskeskus, Rovaniemi.
Page B., Kaika M., 2003. The EU Water Framework Directive: Part 2. Policy innovation and the shifting choreography of governance. European Environment 13: 328-343.

Palm S., Romakkaniemi A., Dennewitz J., Jokikokko E., Pakarinen T., Broman A., 2018. Tornionjoen lohi-, meritaimen- ja vaellussiikakannat - yhteinen ruotsalais-suomalainen biologinen selvitys sopivien kalastussääntöjen arvioimiseksi vuodelle 2018. Institutionen för akvatiska resurser, Lysekil.

Polsko-Niemiecka Komisja Wód Granicznych, 2014. Raporty o jakości polsko-niemieckich wód granicznych Grupy Roboczej W2 „Ochrona Wód”. Wrocław.

Puro-Tahnamaimem A., Viitala L., Lundvall D., Brannstrom G., Lundstedt L., 2001. The River Torne - state and loading of the river system, Regional environmental publications 95/ County Andimistrative Board of Norrbottens Report Series 3/2001. Lapland Regional Environment Centre and County Administrative Board of Norrbotten, Rovaniemen painatuskeskus, Rovaniemi.

Rozporządzenie Ministra Środowiska z dnia 20 sierpnia 2008 r. w sprawie sposobu klasyfikacji stanu jednolitych części wód powierzchniowych. Dz.U. 2008 nr 162 poz. 1008.

Rozporządzenie Ministra Środowiska z dnia 9 listopada 2011 r. w sprawie sposobu klasyfikacji stanu jednolitych części wód powierzchniowych oraz środowiskowych norm jakości dla substancji priorytetowych. Dz. U. Nr 257, poz. 1545.

Rozporządzenie Ministra Środowiska z dnia 30 października 2014 r. w sprawie sposobu klasyfikacji stanu jednolitych części wód powierzchniowych oraz środowiskowych norm jakości dla substancji priorytetowych. Dz.U. 2014 poz. 1482.

Sarmiento-Mirwaldt K., Roman-Kamphaus U., 2013. Cross-border Cooperation in Central Europe: A Comparison of Culture and Policy effectiveness in the Polish-German and Polish-Slovak Border Regions. Europe-Asia Studies 65(8): 1621-1641.

Tornionjoen vesienhoitoalue, 2009a. Tornionjoen vesienhoitoalueen vesienhoitosuunnitelma vuoteen 2015, Vammalan kirjapaino.

Tornionjoen vesienhoitoalue, 2009b. Tornionjoen vesienhoitoalueen toimenpideohjelma pintavesille vuoteen 2015. Vammalan kirjapaino.

Umowa między Rządem Rzeczpospolitej Polskiej i Rządem Republiki Federalnej Niemiec o wspótpracy w dziedzinie gospodarki wodnej na wodach granicznych sporządzona w Warszawie dnia 19 maja 1992 roku.

Umowa w sprawie Międzynarodowej Komisji Ochrony Odry przed Zanieczyszczeniem, sporządzona we Wrocławiu dnia 11 kwietnia 1996.

van der Velde M., 2013. Boring EU Borders? Integration and Mobility across Borders. Eurasia Border Review 3(1): 115-125.

van Houtum H., 2000. III European perspectives on borderlands. Journal of Borderland Studies 15(1): 56-83.

van Houtumn H., 2005. The Mask of the Border. In: D. Wastl-Walter (eds.), The Ashgate Companion to Border Studies. Ashgate: 49-62.

Vattenmyndigheten Bottenviken, Länsstyrelsena Norrbotten, 2010a. Bottenvikens vattendistrict 2009-2015. Länstyrelsens raportserie $2(2)$.

Vattenmydigheten Bottenviken, Länsstyrelsen Norrbotten, 2010b. Unterlag till åtgärdsprogram, Tornedalens vattenparlament - VPO1 2009-2015. 